\title{
TTI'S E-COMMERCE MOTIVATES FARMERS TO PERFORM AT THEIR BEST
}

\author{
I.S.Anugrah ${ }^{1}$, S. Wahyuni ${ }^{2}$ \\ \{iwansetiajie@yahoo.com ${ }^{1}$, maloleyayuk@yahoo.com $\left.{ }^{2}\right\}$ \\ Indonesian Center for Agricultural Socio Economic and Policy Studies-ICASEPS \\ Jalan Tentara Pelajar No 3 B Bogor, West Java-Indonesia ${ }^{1}$ \\ Indonesian Center for Agricultural Socio Economic and Policy Studies-ICASEPS \\ Jalan Tentara Pelajar No 3 B Bogor, West Java-Indonesia ${ }^{2}$
}

\begin{abstract}
Toko Tani Indonesia (TTI) has implemented e-commerce to market products to a greater extent. In 2018, a preliminary study was to examine TTI's implementation of e-commerce, and a subsequent desk study in 2019. The data were collected through interviews with the Food Security Agency, Bumi Pangan Digdaya Agro, TTI, and LUPM. The studies' findings are the following: 1) E-commerce results in several benefits, especially social benefits such as trust, which motivates farmers to do their best in their work for TTI. 2) The number of TTI and LUPM customers who make rice transactions through e-commerce platforms, as well as the volume of rice transactions, increased. In conclusion, the expansion of TTI's e-commerce to other areas should be accomplished through adequate communication and an in-depth study of the targeted areas' potential. This will lead to optimal results. This strategy is critical in promoting agricultural development, especially during the coming new era.
\end{abstract}

Keywords: e-Commerce, social benefits, farmer, transaction, marketing

\section{Introduction}

Toko Tani Indonesia (TTI), also known as Indonesian Farmers Shop was founded in 2016 to keep prices stable and provide people with quality staples foods at lower costs than market prices. TTI was also founded to make food easily accessible by shorthening the market chain form seven to three actors. These three actors are 1) farmers or producers who are members of farmer groups (Kelompok Tani), farmer group unions (Gabungan Kelompok Tani), or Gapoktan, 2) the community's food institution, or Lembaga Pangan Masyarakat (LUPM), which is the Kelompok Tani or Gapoktan that received the Community Food Business Program or Program Usaha Pangan Masyarakat (PUPM) and TTI that directly sell the product to consumers [1].

Since March 2018, TTI E-Commerce has applied to help TTI actors carry out their responsibility, such as TTI can get the rice at anytime they need, and LUPM respond to the request directly. Especially the implementation of ECommerce at TTI also aims at helping BKP's main tasks and function in: (1) Providing and distributing rice effectively in specific periods; (2) Monitoring the status of staple food availability; (3) Simplifying the process of payment transactions; (4) Establishment of a database and reporting system that is very important for the policy strategy.

This paper presents the results of the implementation of E-Commerce in TTI management and the benefits as well as obstacles encountered. The study will useas a basis for policy in massively developing the implementation of ECommerce to achieve food security.

\section{Literature Review}

The implementation of TTI reported by [2] is helping consumers. Unfortunately, [3] claimed that the amount of rice allocated by the TTI program was very low compared to the Indonesian people's consumption needs. This amount was only $0.07 \%, 0.139 \%$ in 2017, and $0.137 \%$ in 2018, which suggests that the Ministry of Agriculture increase TTI's number and existence.. Based on this finding, the number of Gapoktan and TTIs was gradually increased by The Food Security Agency or Badan Ketahanan Pangan [4]. There were 492 PUPM and 1,320 TTIs in 2016 plus 406 Gapoktan and 1,113 TTIs in 2017 and another 500 Gapoktan with 1000 TTIs in 2018, for a total of 1398 Gapoktan 
and 3433TTI spread 7 (seven) provinces of rice centers (South Sumatra, Lampung, Banten, West Java, Central Java, East Java, and West Nusa Tenggara). in 2019 there were 898 PUPMs and 2,433 TTIs spread across 32 provinces.

These conditions require professional TTI management therefore the [5], implemented e-commerce in TTI management. According to [6], e-commerce is a proccess of buying, selling, or exchanging products and services efficiently.. Hence, this paper aims to examine the benefits of and obstacles to TTI e-commerce implementation.

\section{Methodology}

\subsection{Source of Data}

The study was conducted in two steps: 1) Preliminary study after six months of e-Commerce implementation in 2018 with the respondent the initiator of TTI e- Commmerce namely the Food Security Agency or Badan Ketahanan Pangan (BKP), Bumi Pangan Digdaya Agro (BPD) as TTI partners in operating e-Commmerce applications, TTI Center, TTI who sell the product and LUPM for rice commodity entrepreneurs. Data will collect through the interview based on a structural questionnaire on how LUPM and TTI perceived TTI E-Com's implementation includes its benefits and obstacles and the prospect of TTI E-Com. The second step is doing a desk study on data obtained from BPD during 2018 and 2019.

\subsection{Data analysis}

Data and information were analyzed qualitatively based on the "Theory Acceptance Model" (TAM) refer to [7]. Qualitative data were classified into two main objects, which are the benefits and the obstacle of the implementation of TTI E-commerce, then presented descriptively.

\section{Research Result and Discussion}

The implementation of E-Commerce in the management of TTI [8] includes LUPM/ Gapoktan, TTI and TTIC as the liaison that will bring together suppliers and TTI information data system that is handled by the TTI Costumer Team as data manager and application (Figure 1). 


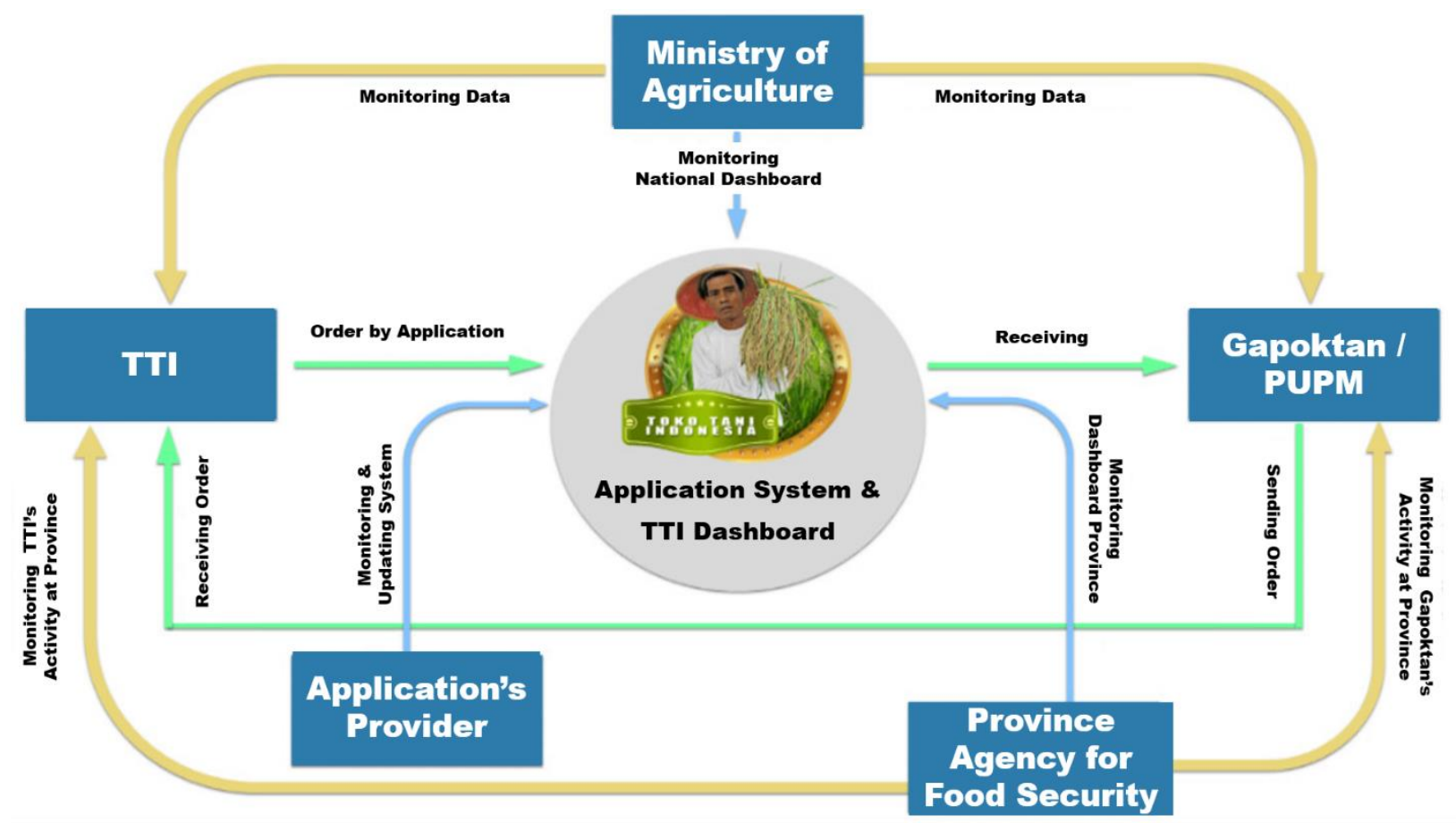

Source: [8]

Figure 1. The mechanism of TTI E-Commerce

\section{Benefits of TTI E-Commerce}

Results from the preliminary survey found some benefits of implementing TTI E-Com (Table 1). Technically, both LUPM and TTI were not dependent on the program's assistant to help them in doing the transaction during the conventional system. They need to fill in the available application as preferred and they could expand their marketing network and monitored the transaction automatically at any time they want.

Table 1. Benefits of TTI E-Com Applications Compare to TTI Conventional

\begin{tabular}{lll}
\hline No & \multicolumn{1}{c}{ TTI Conventional } & \multicolumn{1}{c}{ TTI E-Commerce } \\
\hline Technically & A transaction must be through an assistant & Download the application in Handphone \\
\hline 1 & Networking under an agreement between TTI & respond directly to the TTI order \\
& and Gapoktan/LUPM & \\
3 & Transaction reported manually & LUPM could monitor the transaction through HP \\
4 & Payment system under an agreement & Payment transferred or Cash on delivery (COD)
\end{tabular}

\section{Economically}

5 Payments often not according to agreement $\quad$ No worries on payment

\section{Socially}

6 TTI determines the fate of LUPM Both LUPM and TTI try to be trusted

\section{Source: [9]}

Economically, LUPM has no worries that payment will be delayed or unpaid since the application system option was transferred or cash on delivery (COD). In a conventional system, payments are often not under the agreement, especially when faced by facts that rice has not been sold out yet and LUPM could see piles of rice displayed in the shop. The social benefit reported was "mutual trust" between LUPM and TTI that had been regarded as precious social 
capital [10] that could be found again through TTI E-Com. The transaction will not be made if there is still doubt by either LUPM or TTI. This trust was to motivate both LUPM and TTI to maintain the sustainability of their cooperation. UPM must be trusted in preserving the rice quality and the quantity according to demand by considering the loss of weight during transportation..

\section{Obstacles of TTI E-Commerce}

During the preliminary study LUPM and TTI reported some technical obstacles such as the ability to operate the application andlow signal for LUPM which have not been reached by the internet. Economically, most farmers have limited money to buy a cellphone that could access the E-Com application. These two limitations are ultimately related to the social status where the higher social status of farmers, these two obstacles will not be encountered. The limited volume of rice that could be accessed through the E-Com application somehow made the LUPM find ways to efficiently streamline the delivery process, namely by collecting several orders according to the vehicle's capacity to deliver the rice..

Under the above obstacles and limitations, TTI E-Com has been utilized by TTI (Figure 2). The figure illustrates the TTI transaction and describing the location of the TTI. There are five provinces utilized TTI E-Commerce, in which DKI Jakarta ordered the most (61.37\%); other TTI found are Banten 19.48\%, West Java $18.02 \%$, Bali $0.87 \%$ and TTI Lampung Province $0.26 \%$ (not shown).

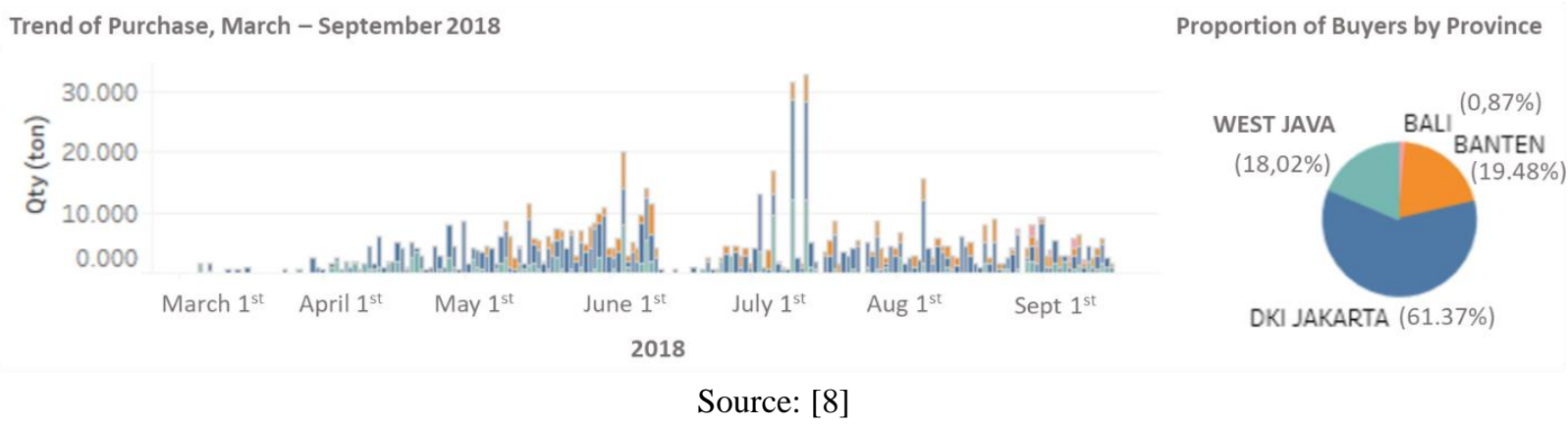

Figure 2. The Utilization of E-Commerce by TTI (March 5, 2018 to September 27, 2018)

Figure 3 illustrates the transaction and the location of LUPM who used the TTI E-Com to service TTI, the most were form LUPM Banten 50.27\%. Others from West Java 26.22\%, East Java 12.21\%, DKI Jakarta $10.21 \%$, Bali 0.87\%, and Lampung $0.25 \%$ (not shown ).

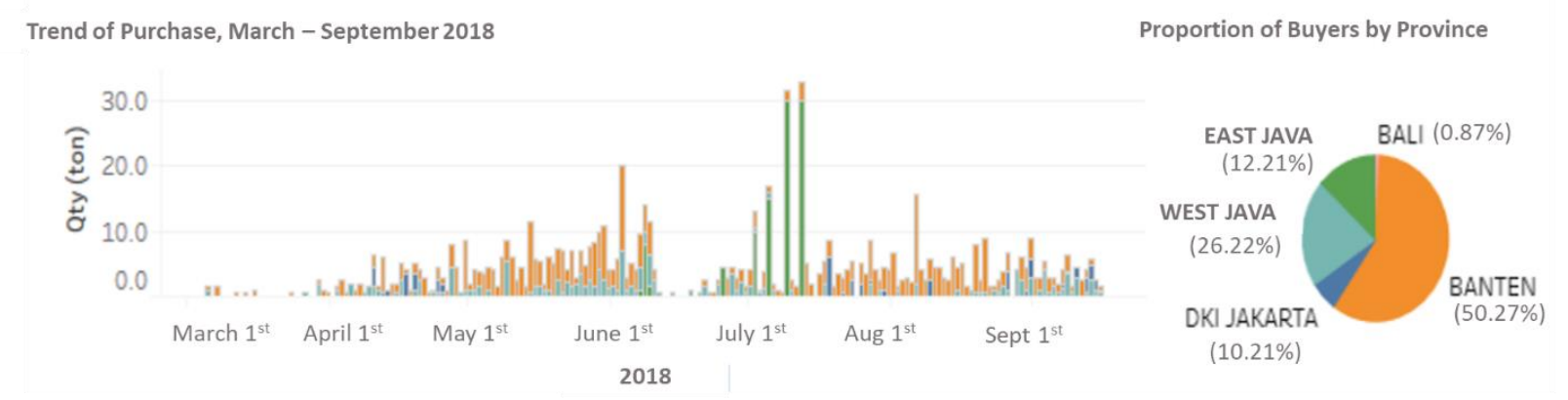

Source: [8]

Figure 3. The Transaction through TTI E-Commerce done by LUPM (March 5, 2018 to September 27, 2018)

\section{Farmers' Performance in TTI E-Commerce}

Based on some benefits from TTI E-Com, many LUPM and TTI were interested in the rice transaction involvement. Table 2 illustrates that compare to data from the preliminary study showed higher rice transactions. This progress proved that farmers who hold trust would give the best services with an average of 5 times increase by the end of 
2019.. That "trust" was significantly had positive correlation for industrial development was reported by [11] while [12] reported that trust is social capital which create bonds between Gapoktan members. Based on these findings, TTI E-Com was a very appropriated technology for TTI management.

Tabel 2. The Increasement of Transaction Through TTI E-Commerce (24 Oct 2018) - (31 Dec 2019)

\begin{tabular}{|c|c|c|c|c|c|}
\hline No & Description & Unit & 24 Oct $2018^{1)}$ & $31 \operatorname{Dec} 2019^{2)}$ & $\begin{array}{l}\text { Increasement } \\
\text { (times) }\end{array}$ \\
\hline 1 & $\begin{array}{l}\text { The total volume of rice transaction from } \\
\text { LUPM to TTI }\end{array}$ & Ton & 863.350 & 3.228 .490 & 3.739 \\
\hline 2 & $\begin{array}{l}\text { Number of TTI registered in the E-Commerce } \\
\text { system }\end{array}$ & Unit & 989 & 4.133 & 4.2 \\
\hline 3 & Number of TTI accessed E-Commerce & Unit & 148 & 844 & 5.7 \\
\hline 4 & $\begin{array}{l}\text { Number of LUPM registered in the E- } \\
\text { Commerce system }\end{array}$ & Unit & 291 & 1.294 & 4.5 \\
\hline 5 & Number of LUPM access E-Commerce & Unit & 67 & 245 & 3.7 \\
\hline \multirow[t]{2}{*}{6} & Total transaction value & IDR & 7.231.163.900 & $56,062,672,400$ & 7.7 \\
\hline & Average & & & & 5.1 \\
\hline
\end{tabular}

Source: ${ }^{1)}[13] ;{ }^{2}[14]$

In 2018 TTI only did the rice transaction by 15\%, it might because they were mainly unable to pay the amount of money under the total price of the volume they ordered.Through the conventional system, TTI was able to pay for the rice they order in stages upon agreement between TTI and LUPM. The payment system is also the reason for rejecting orders that are deemed incompatible with the contract. Through the E-Commerce system, TTI is required to have the capital to purchase the rice and who do not have a transaction card (ATM) have to go to the bank to transfer the money. It takes time and effort to do. Meanwhile, LUPM who have transaction through E-Commerce application has only 23\% of the total LUPM registered in E-commerce. The reason is that the PUPM found difficulty accessing the internet from the village and not utilizing the E-Com application. Even LUPMs who have cellphones cannot access the ECommerce application yet.Regardless of the TTI and LUPM obstacles, data at the end of December 2019 (Table 2) showed the increasing number of TTI and LUPM caused by the province's increment that active using transaction through TTI E-Com (Figure 4). Besides illustrated the percentage of the active TTI and LUPM, Figure 4 also showed the total volume of the transaction from each province, with DKI Jakarta order the most of the rice.

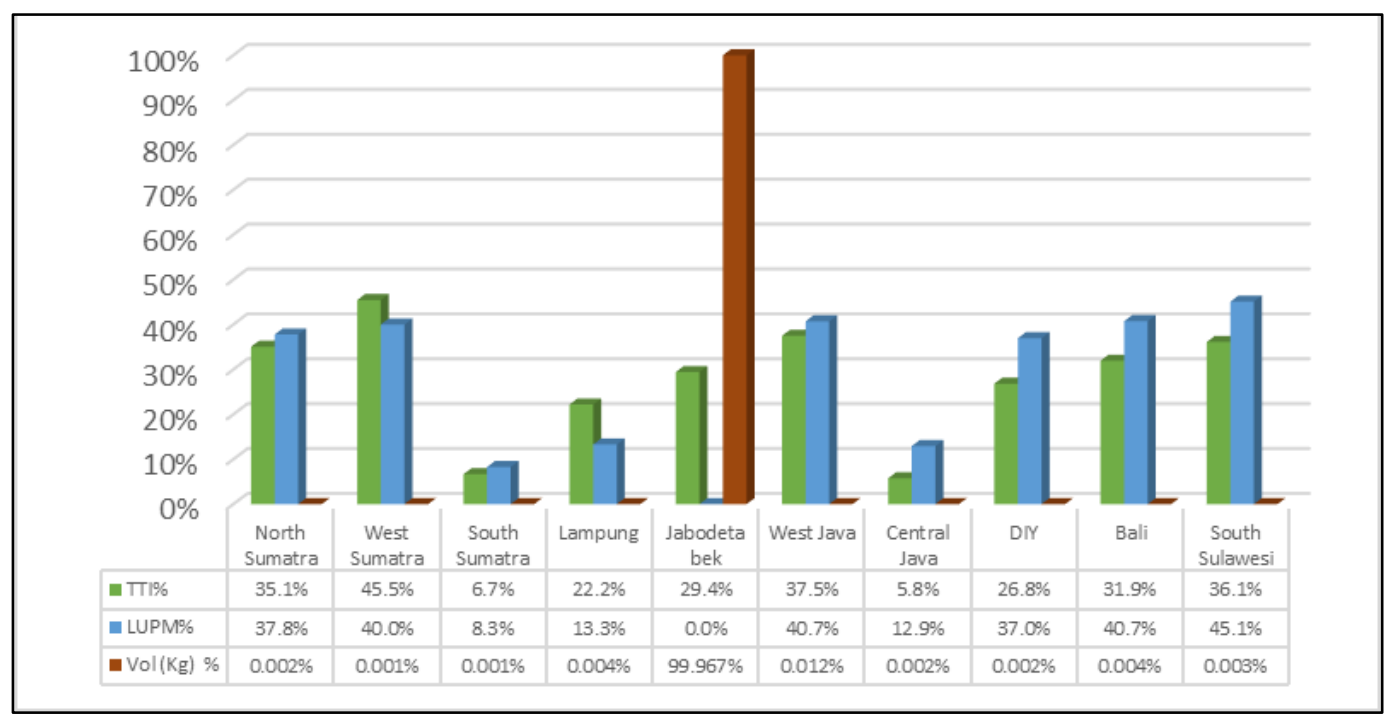

Source : [8]

Figure 4. The Percentage of Active TTI/LUPM in Rice TransactionThrough E-Com and The Volume of Rice delivered in Each Province. 


\section{Conclusion}

E-com has provided benefits for both LUPM and TTI technically, economically and socially. The benefits motivate farmers done their best services as shown by the increasing number of LUPM and TTI from more provinces which made a transaction through E-Com as five times compared to the first semester of the TTI E-Com implementation. The increase of the transaction followed the increament of the total volume of rice.

\section{Implications}

The progress of transactions through E-Com is considered a success story that should inform another LUPM and TTI in all provinces. Due to the new era during the Covid 19 pandemic situation, the online system for farmers and TTI activity is pivotal. The government should facilitate farmers and TTI with technical assistance and guidance in the capacity of TTI E-Com. This effort must be followed by holistic data about the target areas' potential, where the facilitation would conduct. It is also essential to conduct regular monitoring and evaluation under the global situation with respondents who can represent the number and location of the spread of TTI and LUPM.

\section{Acknowledgments}

Thank you to the Head of the Center for Socio-Economic and Agricultural Policy - Ministry of Agriculture for providing the opportunity to participate in the activities of The 3rd International Conference of Economics, Business, and Entrepreneurship-ICEBE, October 1st, 2020. We would like to thank all committees and other participants during the implementation of the activity ICEBE until the publication of this proceeding.

\section{REFERENCES}

[1] [KEMENTAN] Kementerian Pertanian. (2017). Sistem Informasi Perdagangan Elektronik Pangan Pokok dan Strategis Berbasis Teknologi Informasi pada Kegiatan Pengembangan Usaha Pangan Masyarakat (PUPM) melalui Toko Tani Indonesia (TTI). Jakarta: IAARD PRESS.

[2] Sulaiman, A.A. I.K. Kariyasa, K.Subagyono, Hermanto, A. Agustian, I.S. Anugrah, I.P. Nashwari, S. Herodian. 2018. Toko Tani Indonesia : Membenahi Rantai Pasok dan Stabilisasi Harga Pangan. IAARD PRESS. Jakarta.

[3] Anugrah, I.S., \& Wahyuni, S. (2019). Toko Tani Indonesia: National Program for Shortening Rice Supply Chain: Proceedings Conference of Advance in Economic, Business and Management Research Vol 98, (pp:117-121). Jakarta, Indonesia: Ministry of Trade.

[4] [BKP] Badan Ketahanan Pangan. (2016). Kiprah Toko Tani Indonesia: untuk kesejahteraan petani dan masyarakat. Jakarta: BKP - Kementan. IAARD. Press.

[5] [KEMENTAN] Kementerian Pertanian. (2018). Pedoman Teknis Pengembangan Usaha Pangan Masyarakat melalui Toko Tani Indonesia, Tahun 2018. Jakarta.

[6] Wibowo, E. A. (2016). Pemanfaatan Teknologi E-Commerce Dalam Proses Bisnis. Equilibiria, 1(1), 95-108. Retrieved from http://journal.unrika.ac.id/index.php/equi/article/view/222

[7] Yulistia, Y. (2017). Analisis Pengaruh Efektivitas Dan Manfaat E-Commerce Terhadap Sikap Dan Perilaku Pengguna Dengan Menggunakan Metode TAM (Studi Kasus: UKM Kota Palembang). JATISI (Jurnal Teknik Informatika Dan Sistem Informasi), 4(1), 93-100. Retrieved from https://doi.org/10.35957/jatisi.v4i1.91.

[8] [BPD Agro] Bumi Pangan Digdaya Agro. 2018. Toko Tani Indonesia : Pangan Murah Berkualitas. Info Pasar Tani dan Aplikasi E-Commerce. Bahan Presentasi Tim BPD Agro pada FGD Hasil Penelitian Tim TTI PSEKP, Tanggal 30 November 2018 di PSEKP Bogor.

[9] Anugrah, I. S., Hermanto, Wahyuni, S., Suryani, E., \& Hestina, J. (2018). Desain dan Implementasi Toko Tani Indonesia (TTI) dalam Upaya Pengendalian Harga Pangan Pokok dan Strategis. Bogor, Indonesia: Pusat Sosial Ekonomi dan Kebijakan Pertanian, Bogor.

[10] Saheb, Slamet Y and Zuber A. 2013. Peranan Modal Sosial Bagi Petani Miskin Untuk mempertahankan Kelangsungan Hidup Rumah Tangga Di Pedesaan Ngawi (Studi Kasus Di Desa Randusongo Kecamatan Gerih Kabupaten Ngawi Provinsi Jawa Timur. Jurnal Analisa Sosiologi, 2 (1): 17 - 34.

[11] Sawitri D and Ishma FS. (2014). Modal Sosial Petani dan Perkembangan Industri di Desa Sentra Pertanian Kabupaten Subang dan Kabupaten Karawang. Jurnal Perencanaan Wilayah dan Kota, 25 (1), 17-36. 
[12] Trisnanto TB, Fitriani and Fatih C. (2017). Membangun modal sosial pada gabungan kelompok tani. Ejournal.unair.ac.id. Masyarakat, Kebudayaan dan Politik , 30(1) 59-67. Retrieved from https://www.google.com/search?client=firefox-b-d\&q=kepercayaan+antar+petani

[13] Indrawan. (2018, June). Toko Tani Indonesia: Pangan Murah Berkualitas. Info Pasar Tani dan Aplikasi ECommerce. Pertemuan Kegiatan Penelitian Tahun 2018. Agro, BP D, Jakarta.

[14] Indrawan. (2019, September). Toko Tani Indonesia: Pangan Murah Berkualitas. Info Pasar Tani dan Aplikasi E-Commerce. Laporan Kegiatan Penelitian Tahun 2019 Pusat Sosial Ekonomi dan Kebijakan Pertanian, Bogor. 